\title{
Marketing capability and export performance: The moderating effect of export performance
}

\author{
A. Al-Aali* \\ Department of Marketing, College of Business Administration \\ King Saud University, Riyadh, Saudi Arabia \\ alaali@KSU.EDU.SA \\ J-S. Lim \\ Department of Marketing and International Business, \\ College of Business and Innovation, \\ The University of Toledo, Toledo, Ohio, 43560, USA \\ T. Khan \\ Department of Marketing, College of Business Administration \\ King Saud University, Riyadh, Saudi Arabia \\ M. Khurshid \\ Department of Management, College of Business Administration \\ King Saud University, Riyadh, Saudi Arabia
}

\begin{abstract}
As global competition around the world continues to intensify, firms are seeking strategies that will increase export performance. The purpose of this study is to examine the moderating effect of export involvement on the relationships among marketing capabilities, export performance, and export intensity. The main study was conducted by a questionnaire using the Saudi Arabia export ventures as the sampling frame. Data was analyzed with LISREL to test the moderating effect of export involvement. This study found that export involvement moderates the relationships among marketing capabilities, export performance, and export intensity. Product and distribution capabilities show a significant direct effect on export performance for the low involvement exporters. For the high involvement exporters, the promotion and distribution capabilities have a significant effect on export performance. The impact of the three marketing capabilities on export performance is moderated by export involvement. Depending on the level of export involvement, firms should selectively target different marketing capabilities to improve export performance. This paper fills the gap in our understanding of the differential impact of various marketing capabilities on export performance for firms in different levels of export involvement.
\end{abstract}

*To whom all correspondence should be addressed.

\section{Introduction}

As global competition around the world continues to intensify, firms are seeking strategies that will increase export performance. The development and implementation of effective marketing strategies are particularly important for firms pursuing global market expansion. When the world entered the twenty-first century we witnessed some dramatic transformations in international trade: growing liberalization of trading systems, expansion of regional economic integration, excessive liquidity in financing cross-country purchases, and increased connectedness with customers and marketing partners due to major advances in information, communication, and transportation technologies (Keegan, 2002). This has led to the emergence of a business environment that has never been so globalized, interdependent, and connected, widening both the scope and scale of opportunities open to sellers (Leonidou, 2004).

Past research studies in international marketing identified the importance of understanding the relationship between marketing capabilities and export performance (Leonidou, Katsikeas \& Samiee, 2002; Sousa \& Alserhan, 2002; Tooksoon \& Mohamad, 2010; Zou, Fang \& Zhao, 2003). According to dynamic capabilities' theory (Newbert, 2007; Zott, 2003), firm performance over time is primarily determined by the firms' capabilities of acquiring and deploying resources to match their market environment (e.g., Eisenhardt \& Martin, 2000; Makadok, 2001; Teece \& Al-Aali, 2011; Teece, Pisano \& Shuen, 1997). Firm capabilities consist of complex coordinated patterns of skills and knowledge that are uniquely embedded in processes that are performed well, relative to competitors (Bingham, 
Eisenhardt \& Furr, 2007; Ethiraj et al., 2005). Marketing capabilities are defined as complex bundles of skills and accumulated knowledge, exercised through marketing processes, which enable a firm to coordinate marketing activities and make use of its assets (Day, 1994). Thus, marketing capabilities are firm-specific and could provide superior market sensing, customer linking, and channel bonding capabilities in global markets (Blesa \& Ripolle, 2008). These capabilities can lead to global market success. Marketing capabilities enable exporting firms to implement new export marketing strategies to reflect changing global market conditions through transforming and combining available resources in new and different ways.

For exporting firms, it is important to understand the role of marketing capabilities within the global marketing context. Many research studies call for additional research to better understand the differing impact of various marketing capabilities on export performance (e.g., Hooley et al., 2005). Although the concept of marketing capabilities has received increased attention in marketing and strategy literature, little research has been devoted to exploring the differential influence of marketing capabilities on export performance for firms with varying degree of export involvement (Yeniyurt, Cavusgil \& Hult, 2005).
Therefore, the purpose of this study is to examine the moderating effect of export involvement on the relationships among marketing capabilities, export performance, and export intensity. The findings of this study can provide knowledge of the relative influence of different marketing capabilities on export performance. The results can identify which marketing capabilities are critical to firms with different levels of export involvement in global markets.

\section{Theoretical framework}

This study develops a conceptual model that captures the relationships among marketing capabilities, export performance, export intensity, and export involvement. Figure 1 shows the proposed model. As shown in the Figure 1 model, marketing capabilities have a positive effect on export performance leading to export intensity. The relationships between marketing capabilities and export performance are moderated by export involvement. In addition, export involvement also moderates the relationship between export performance and export intensity.

\section{Marketing Capability}

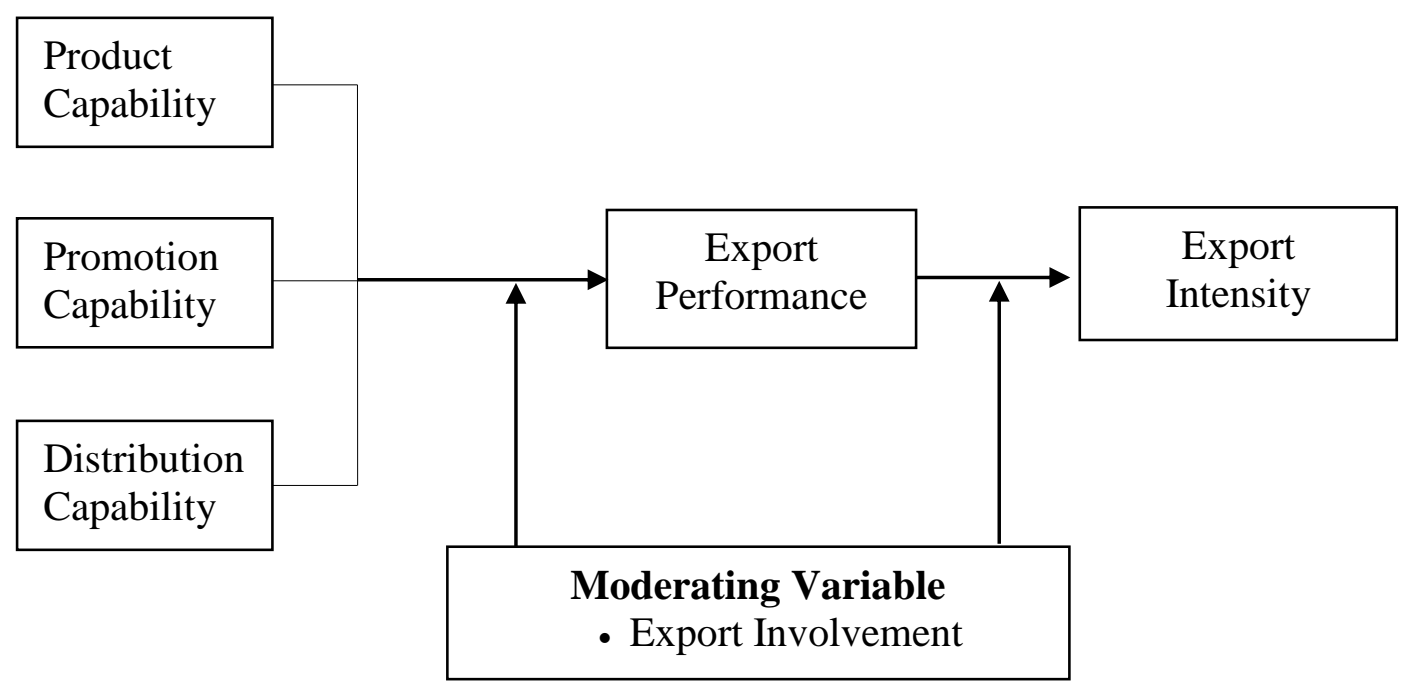

Figure 1: Conceptual model

\section{Marketing capabilities}

Strategic management and marketing literatures suggest that firm capabilities in functional areas can lead to positive performance. The concept of developing capability and its impact on performance has been an important focus within the marketing field in recent years. Marketing capability involves the integrative process in which a firm uses its tangible and intangible resources to understand complex consumer specific needs, achieve product differentiation relative to competition, and achieve superior brand equity (Day, 1994; Nath, Nachiappan \& Ramanathan, 2010; Song et al., 2007).
Marketing resources and capabilities, exercised through marketing processes, can be a significant contributing factor to a firm's competitive advantage in global markets (Hooley et al., 2005; Weerawardena, 2003a). Previous research studies have identified various types of marketing capabilities that can enhance a firm's competitive advantage and business performance. Day (1994) proposed inside-out, outside-in, and spanning capabilities: the first referring to the ability of a company to identify customers' needs, the second referring to the ability to build relationships with them, and the third referring to the ability to integrate insideout and outside-in capabilities. In addition, other researchers identified the ability to learn from the market $(\mathrm{Li} \&$ 
Calantone,1998; Slater \& Narver, 1995; Weerawardena, 2003a \& b), the capacity to collect, disseminate and use market-based information (Jaworski \& Kohli, 1993; Narver \& Slater, 1990), the ability to create mutual trust and commitment between partners (Hooley et al., 2005), as key to the growth of organizational performance.

Based on the dynamic capabilities' perspective, the above marketing capabilities are expected to influence firm's performance positively because they are based on the firm's capability to manage information and adapt to the environment. Moreover, these capabilities are easily transferable between different countries, as they do not depend on the context in which the firm carries out its business activity but rather are based on the management of information and adaptation to foreign markets (Fernhaber \& McDougall, 2005). Marketing literature suggests that firms use capabilities to transform resources into outputs driven by their marketing mix strategies and that such marketing capabilities can affect their business performance (Vorhies \& Morgan, 2003 \& 2005; Morgan, Vorhies \& Mason, 2009). Marketing mix capabilities are utilized to develop and implement the company's product, pricing, distribution, and promotion strategy in export markets that are key to superior export performance (Leonidou et al., 2002).

Among the marketing mix capabilities, product, distribution, and promotion capabilities are included in this study as they are transferable between countries, can be easily adapted to various foreign markets, and can be managed or controlled fully by exporting firms. While pricing capability can influence export performance, it is not included in this study considering the limited flexibility in making strategic pricing decision in global markets and the small variability among exporting firms. Next section discusses how the effects of the three marketing capabilities on export performance are moderated by the level of export involvement.

\section{Moderating effect of export involvement}

Firms encounter unique challenges in the transformation of resources and developing marketing mix strategies in global markets. Global market conditions may require firms to develop and implement a distinctive mix of products, services, packaging, and other marketing mix elements tailored to local needs and preferences (Blesa \& Ripolle, 2008; Moorman \& Slotegraaf, 1999). The internationalization process of firms requires transformation of human, financial, and other resources to international activities abroad. Without proper resource allocation, a firm may find itself in the initial stages of exporting for extended periods of time and may lack significant progress in tapping international markets. The extent to which a company is dependent on export markets and to what extent it commits its resources to export activities can determine the level of export involvement. Firms in the advanced stages of export involvement exhibit a greater internal capability to develop a sound competitive marketing mix strategy and commit to the allocation and organization of export related resources (Diamantopolous \& Inglis, 1988; Leonidou, 2011; Lim, Sharkey \& Kim, 1996). In utilizing the allocated resources, firms should selectively develop marketing capabilities to achieve higher export performance. Different marketing capabilities are required for success in global markets as firms face highly specialized circumstances during various stages of the internationalization process. Therefore, it is important for firms to focus on appropriate marketing capabilities with consideration of the level of export involvement.

Previous research studies report a positive relationship between product capability and export performance (Dominguez \& Sequira, 1993; Leonidou et al., 2002; Louter, Ouwerkerk \& Bakker, 1991). As differential product quality is more difficult to achieve due to rapid imitation of competitors, the role of product innovation is becoming increasingly vital to achieve export performance (Lim, Sharkey \& Heinrichs 2006; Zhang, Cavusgil \& Roath, 2003). Lages, Silva and Styles (2009) contend that product strategy is the key driver of export performance and product quality is the top determinant of export performance. Firms with new product development capability can effectively develop and manage new product and service offerings to meet export customers' needs. Murray, Gao and Kotabe (2011) report a significant positive effect of new product development capability on the business performance of export ventures.

In many cases, firms need to make product modifications to better position the product for local consumption. The degree of modification ranges from simple translation into a foreign language, changes in packaging and product-use instructions, and warranties to complete redesign or redevelopment of products and services. Unique products can enhance firms' export performance in the initial stages of international involvement (Lim, Sharkey \& Kim, 1993). The importance of product capability as a competitive tool for export diminishes as firms progress along the export development stages (Dominguez \& Sequeira, 1993; Cavusgil, Chang \& Zhang, 2003). Hence, the following hypothesis is presented.

H1: The relationship between product capability and export performance is moderated by export involvement. The effect of product capability on export performance is stronger when a firm's export involvement is low rather than high.

Promotion capability in global markets involves integration of all marketing related activities of a firm utilizing superior market knowledge from global customers and competititors. As direct involvement with customers in international markets can create collective knowledge of the team and firm through trial and error (Zahra, Ireland \& Hitt, 2000), export managers need to devise incremental promotional strategies characterized by gradual adjustments to the export market conditions (Lages, Jap \& Griffith, 2008; Özsomer \& Gençtürk, 2003).

Promotion capability allows firms to adapt to foreign markets and target the right customers with effective integrated marketing communications (Blesa \& Ripolle, 2008). In the later stages of export development, firms with superior marketing communication capability are able to persuade global consumers to purchase their products that 
are available in the targeted foreign markets (Murray et al., 2011). Hultman, Katsikeas and Robson (2011) also show that export promotion strategies are more effective in increasing export sales for firms with greater experience in the specific foreign markets. These discussions lead to the following hypothesis.

H2: The relationship between promotion capability and export performance is moderated by export involvement. The effect of promotion capability on export performance is weaker when a firm's export involvement is low rather than high.

Distribution capability in the international channel is essential for many firms that are involved in the international arena. Distribution capability, whether through distributors or direct international channels, allows export firms access to customers in foreign markets, gain important local-market knowledge, and provide necessary marketing services (Bello, Chelariu \& Zhang, 2003; Wilkinson \& Brouthers, 2006). Previous research studies have reported that distribution network availability and a cooperative partnership between the manufacturer and the export channel have a positive effect on export performance (Lages \& Montgomery, 2004; Lee \& Griffith, 2004; Leonidou et al., 2002; Ling-yee, 2004; Sousa \& Bradley, 2009; Style \& Ambler, 2000).

Distribution capability can have differential effects on the export performance of firms due to the different requirements and aspirations of non-exporters, early exporters, and advanced exporters (Leonidou, 2004; Leonidou \& Katsikeas, 1996). Firms in their early stage of export development would have the greater difficulty in acquiring information about foreign markets and establishing a close relationship with distributors in the foreign market. For the low export involvement firms, distribution capability can provide the support and collaboration needed to manage the export channels successfully leading to new market development and increased export sales. On the other hand, high export involvement firms have the necessary export experience and resources and are successfully managing the distribution channels in the current export markets. For these active and advanced exporters, the added control on distribution activities and distribution channel relationships with the superior distribution capability would provide marginal export sales increase in global markets (Eusebio, Andreu \& Belbeze, 2007). Extrapolating from these studies, the following hypothesis is presented.

H3: The relationship between distribution capability and export performance is moderated by export involvement. The effect of distribution capability on export performance is stronger when a firm's export involvement is low rather than high.

Superior export performance is of vital interest to business managers who perceive exporting as a tool to boost corporate growth, increase capacity utilization, improve financial performance, strengthen competitive edge, and even ensure company survival in a highly globalized marketplace (Bo, 2007; Eusebio et al., 2007). Engagement in export operation is vital for many firms in spreading business risks across different markets and generating more revenues and funds for reinvestment and further growth (Czinkota \& Ronkainen, 2001; Terpstra \& Sarathy, 2000). When firms experience saturated domestic markets or need additional growth, they rely more on foreign markets for increasing revenue and sales. Exporting firms are increasingly focusing on export intensity as defined by the export to total sales ratio. Export intensity is considered as a proxy of export performance indicating the degree of multinationality of a specific firm (Brouthers \& Nakos, 2005; Katsikeas, Leonidou \& Morgan, 2000; Lu \& Beamish, 2001).

Export success in early stages of export development can make a greater contribution to export intensity leading to higher degree of multinationality of a firm. Brouthers et al. (2009) argue that firms in the early stages of internationalization may engage in exporting as a means of exploration or testing the waters. In the early stages, export success generating sales and profits becomes increasingly salient and, in consequence, export firms put more emphasis on achieving higher sales and profits from existing export markets through its marketing program (Lages et al., 2008). Hence, the following hypothesis is presented.

H4: The relationship between export performance and export intensity is moderated by export involvement. The effect of export performance on export intensity is stronger when a firm's export involvement is low rather than high.

\section{Methodology}

\section{Sample and procedure}

The focus of this study is the main exporters from Saudi Arabia. The sampling framework was obtained in electronic format from the Ministry of Commerce and Industry (2009) of Saudi Arabia which issues the Certificate of Origin (COO) that is required for exporting. The list contained the names of 1278 firms that were issued the COO. A simple random sample of 34 per cent yielded 511 firms that were contacted to participate in the study. A survey method was utilized in this study. The firms thus selected for the study were contacted and asked to have the person most involved with the daily administration of the exporting functions complete the survey. Each firm received a cover letter and the questionnaire along with complete information such as the authors' e-mails, fax numbers, and telephone numbers, etc. for receiving the responses. Each firm was duly followed up on to ensure their responses.

The instrument was prepared in three stages. The first stage consisted of refining the English version of the survey instrument and cover letter. The initial survey format was developed based upon extant literature on the subject. Next, the survey instrument was translated and back translated. In order to avoid translation errors, a different researcher translated the questionnaire into English. During this stage, the content and face validity of the items were assessed by two judges (university professors in marketing); each judge was asked to assess how representative each item was of 
final construct. The survey was revised according to their comments. The survey instrument contained question items measuring international marketing capabilities, export performance, firm exporting behavior, and respondent characteristics. Respondents were first asked the qualifying question of whether they had exported before or were currently exporting. Only those firms that had exporting experience were qualified to participate in the survey.

A total of 239 questionnaires were returned. After data checking, 17 questionnaires were deemed unusable. The analysis was carried out on 222 respondents yielding a response rate of 43,4 per cent. The average export experience of responding firms is 12,6 years of which 66,2 per cent have a separate export department. The export departments, on average, were established 11,5 years ago with 8 per cent of them being established over 21 years ago. Those exporters with a separate export department, on average, have 9,7 full-time staff. The responding firms' twoyear average of export sales to total sales (export intensity) was 29,34 per cent. Around two-thirds $(65,8$ per cent) of the respondents were export/marketing managers.

\section{Variables}

Respondents were asked to indicate their perception of international marketing capabilities when compared to their competitors in overseas markets. Appendix shows the specific question items used in this study. The three marketing capabilities are measured by two-item five-point rating scales ranging from (1) Much lower to (5) Much higher. Product capability measures a firm's exported products' quality and degree of differentiation. Promotion capability is measured by assessing a firm's promotion budget and effectiveness of the promotion activities in international markets. Distribution capability captures a firm's distribution budget and effectiveness of the distribution activities in international markets. This study's operationalization of marketing capabilities is consistent to Zou et al. (2003).

Export performance is measured by a four-item five-point Likert scale. These four items capture the perceived overall company's export performance compared to that of competitors in the primary overseas market, the exporting contribution to a firm's sales growth, market share growth, and increased competitiveness. These items are adapted from Diamantopoulos and Winklhofer (2001) and Katsikeas et al. (2000).

Export intensity is measured by the average of the current and past year percentages of exporting sales to the total sales (Al-Aali, 1995; Beamish \& Munroe, 1987). Export involvement is measured by two items capturing the existence of export department and the size of the export department's full time staff. The respondent firms are classified into low and high export involvement groups using the median split method. Firms without an export department or with an export department of five or less fulltime staff are classified into the low export involvement group and firms with an export department of 6 or more fullstaff are classified into the high export involvement group. Out of the 222 responding firms, 112 firms are classified into the low export involvement group and 110 firms are classified into the high export involvement group.

\section{Analysis and results}

\section{Confirmatory factor analysis}

The measurement properties were assessed in one confirmatory factor analysis (CFA) using LISREL 8,8. Multiple fit criteria were presented to rule out measuring biases inherent in the various measures. Table 1 presents scale means and standard deviations for the low and high involvement groups and confirmatory factor analysis results for the total respondents. The fit indices showed that the model resulted in a good fit to the data (Chi-Square $=35,15$ with 21 d.f., $p=0,027$, Goodness of Fit Index (GFI) =0,97, Normed Fit Index (NFI) $=0,97$, Comparative Fit Index $(\mathrm{CFI})=0,99$, Root Mean Square Residual $(\mathrm{RMR})=0,035)$.

All the items loaded significantly on the expected constructs. Composite reliabilities were calculated for the four constructs (Fornell \& Larcker, 1981). The composite reliabilities were $0,73,0,83$, and 0,85 for the product, promotion, and distribution capabilities, respectively. The factor loadings ranged from 0,73 to $0,90(\mathrm{p}<, 01)$ for the product, promotion, and distribution capabilities. The export performance scale shows the composite reliability of 0,84 , with factor loadings ranging from 0,84 to $0,90(\mathrm{p}<, 01)$. These results indicate convergent validity of the measures. The discriminant validity was tested with the procedure suggested by Anderson (1987) and Bagozzi and Phillips (1982). The chi-square difference tests were performed for all possible pairs of constructs. In all pairs of constructs, the critical value was exceeded indicating discriminant validity. The mean values of the three marketing capabilities and export performance ranged from 2,79 to 3,73 for the low export involvement group and from 3,11 to 3,87 for the high export involvement group. The high export involvement group shows consistently higher mean values than the low export involvement group for all five measures. The export intensity of the high export involvement group $(36,27 \%)$ was much higher than the export intensity of the low export involvement group $(22,2 \%)$.

\section{Testing hypotheses}

Data was analyzed by structural equation analysis. Figure 1 depicts the conceptual model that was estimated by LISREL 8,8 . Separate structural-equation models were estimated for the low and high export involvement groups. Table 2 provides the standardized LISREL estimates and goodnessof-fit indices for the Figure 1 model. The $\chi^{2}$ for the low involvement group is 6,02 with 6 degrees of freedom ( $\mathrm{p}=$ ,42). The normed fit index (NFI) is ,96 with relative fit index (RFI) of ,93. The root mean square residual is 0,045 . Similarly, The $\chi^{2}$ for the high involvement group is 0,77 with 6 degrees of freedom $(\mathrm{p}=, 99)$. The normed fit index (NFI) is ,99 with relative fit index (RFI) of ,98. The root mean square residual is 0,018 . The goodness of fit indices and small RMSR values suggest that the overall Figure 1 model is supported by the data. 
Table 1: Means, standard deviations, and confirmatory factor analysis results

\begin{tabular}{|c|c|c|c|c|c|c|}
\hline \multirow{2}{*}{ Factor } & \multicolumn{2}{|c|}{ Low ExpInv Group $(n=112$} & \multicolumn{2}{|c|}{ High ExpInv Group $(n=110)$} & \multirow{2}{*}{$\begin{array}{l}\text { Composite } \\
\text { Reliability }\end{array}$} & \multirow{2}{*}{ Factor Loadings } \\
\hline & Mean & S.D. & Mean & S.D. & & \\
\hline Product Capability & 3,73 & 0,71 & 3,82 & 0,67 & 0,73 & $0,73-0,79$ \\
\hline Promotion Capability & 2,79 & 0,82 & 3,11 & 0,87 & 0,83 & $0,83-0,84$ \\
\hline Distribution Capability & 2,85 & 0,93 & 3,32 & 0,73 & 0,85 & $0,80-0,90$ \\
\hline Export Performance & 3,46 & 0,82 & 3,87 & 0,64 & 0,84 & $0,84-0,90$ \\
\hline Export Intensity & 22,2 & 18,94 & 36,27 & 27,71 & N.A. & N.A. \\
\hline
\end{tabular}

Note: Goodness of Fit Indices: $\chi^{2}=35,15$ with 21 d.f.; $p=0,027$; Goodness of Fit Index (GFI) = 0,97; Normed Fit Index (NFI) = 0,97; Comparative Fit Index $(\mathrm{CFI})=0,99$; Root Mean Square Residual $(\mathrm{RMR})=0,035$. ExpInv = Export Involvement; N.A. = Not Applicable.

Estimated path coefficients are also shown in Table 2. For the low export involvement group, the paths from product capability and distribution capability to export performance were significant. The path from export performance to export intensity was also significant. However, the path from promotion capability to export performance was not significant. For the high export involvement group, the paths from promotion capability and distribution capability to export performance were significant. The path from export performance to export intensity was also significant. However, the path from product capability to export performance was not significant.

To test hypotheses, a series of two-tailed t-tests were conducted. T-tests can assess whether the difference in the strength of the path coefficients between the low and high export involvement groups is statistically significant. To test hypothesis 1 , the path coefficient from product capability to export performance was compared between the low and high export involvement groups. For the low export involvement group, the coefficient was significant $(\gamma$ low $=$ $0,19, \mathrm{p}<, 05)$. However, for the high-export involvement group, the coefficient was not significant $(\gamma$ high $=-0.06, \mathrm{p}>$ .05). The comparison between the two coefficients revealed that the path coefficient for the low export involvement group was significantly stronger than the path coefficient for the high export involvement group $(\mathrm{t}=2,78, \mathrm{p}<0,01)$, supporting Hypothesis 1. Hypothesis 2 was tested by comparing the path coefficient from promotion capability to export performance between the low and high export involvement groups. For the high export involvement group, the coefficient was significant ( $\gamma$ high $=0,24, \mathrm{p}<, 05)$. However, for the low export involvement group, the coefficient was not significant $(\gamma$ low $=-0,02, p>, 05)$. The comparison between the two coefficients revealed that the path coefficient for the high export involvement group was significantly stronger than the path coefficient for the low export involvement group $(\mathrm{t}=-2,47, \mathrm{p}<0,01)$, supporting Hypothesis 2. Comparison of the path from distribution capability to export performance $(\gamma$ low $=0,44, \mathrm{p}<, 05$ vs. $\gamma$ high $=0,24, p<.05)$ revealed that the coefficients were not significantly different $(\mathrm{t}=1,82, \mathrm{p}>, 05)$. Although distribution capability shows a significant effect on export performance for both the low and high export involvement groups, the difference in the strength of the coefficients is not significant. These results do not provide support for Hypothesis 3.

Hypothesis 4 was tested by comparing the path coefficient from export performance to export intensity between the low and high export involvement groups. For the low export involvement group, the coefficient was significant $(\beta l o w=$ $0,47, \mathrm{p}<, 05)$. For the high export involvement group, the coefficient was also significant $(\beta$ high $=0,26, \mathrm{p}<, 05)$. The comparison between the two coefficients revealed that the path coefficient for the low export involvement group was significantly stronger than the path coefficient for the high export involvement group $(\mathrm{t}=2,45, \mathrm{p}<0,01)$, supporting Hypothesis 4.

\section{Discussion}

This study evaluated the moderating effect of export involvement on the relationships among three marketing capabilities, export performance, and export intensity. The positive effect of product capability on export performance is stronger for the low involvement exporters than the high involvement exporters. On the other hand, the effect of promotion capability on export performance is stronger for the high involvement exporters than the low involvement exporters. This suggests that product capability has much greater influence on export performance for the low involvement exporters than the high involvement exporters. Promotion capability shows much greater influence on export performance for the high involvement exporters than the low involvement exporters. 
Table 2: Parameter estimates and t-values

Export Involvement (ExpInv)

Path

Low ExpInv Group

High ExpInv Group

Test of the

Difference

t-value

\begin{tabular}{lcc}
\hline ProdCap $\rightarrow$ ExPerf & $0,19(2,11)^{*}$ & $-0,06(-0,66)$ \\
PromoCap $\rightarrow$ ExPerf & $-0,02(-0,21)$ & $0,24(2,33)^{*}$ \\
& & \\
DistCap $\rightarrow$ ExPerf & $0,44(4,04)^{* *}$ & $0,24(2,23)^{*}$ \\
& & \\
ExPerf $\rightarrow$ ExInt & $0,47(5,60)^{* *}$ & $0,26(2,81)^{* * *}$ \\
& & \\
Goodness of Fit Indices: & & $0,77 / 6$ \\
$\chi^{2} /$ d.f. & $6,02 / 6$ & 0,99 \\
P-Value & 0,42 & 0,99 \\
Normed Fit Index (NFI) & 0,96 & 0,98 \\
Relative Fit Index (RFI) & 0,93 & 0,018 \\
Root Mean Square Residual (RMR) & 0,045 &
\end{tabular}

Note: ( ) are t-values; * $\mathrm{P}<, 05, * * \mathrm{P}<, 01$. ProdCap: Product Capability; PromoCap: PromotionCapability; DistCap: Distribution Capability; ExPerf: Export Performance; ExInt: Export Intensity.

This study found significant effects of the product and distribution capabilities on export performance for the low involvement exporters. For the high involvement exporters, the promotion and distribution capabilities have a significant effect on export performance. Past research has consistently found that international marketing capabilities are positively related to export performance (Blesa \& Ripolle, 2008; Tooksoon \& Mohamad, 2010; Tsai \& Shih, 2004; Osman, Ramayah \& Ng, 2009).

Among the three marketing capabilities, distribution capability shows a significant effect on export performance for both the low and high involvement exporters. This suggests the importance of creating and building the distribution capability in improving export performance (Lages \& Montgomery, 2004; Leonidou et al., 2002; Sousa \& Bradley, 2009). Firms need to develop efficient distribution channels regardless of their level of export involvement. In addition to the distribution capability, promotion capability shows a significant positive effect on export performance for the high involvement exporters. High involvement exporters need to cultivate their promotion capability to improve their export performance. For the low involvement exporters, product capability also shows a significant effect on export performance, although its path coefficient is smaller than the path coefficient of the distribution capability. This result is consistent with previous research findings that product capability is a critical factor to export performance in the early stages of export development (Lim et al., 1993; Tooksoon \& Mohamad, 2010). This study also found that the effect of export performance on export intensity is much greater for the low involvement exporters than the high involvement exporters. This suggests that export performance influences export intensity more positively for the low involvement exporters than the high involvement exporters.

\section{Conclusions}

This study has demonstrated that exporters' marketing capabilities determine their export performance. Thus, firms that enjoy superior marketing capabilities will be better placed to devote efforts to international marketing business and reap its benefits. Although recent export studies have shown positive relationships between marketing capabilities and export performance (e.g., Leonidou et al., 2002; Sousa \& Alserhan, 2002; Tooksoon \& Mohamad, 2010; Zou et al., 2003), the moderating effect of export involvement on the relationships between marketing capabilities and export performance has not been well understood. This study voids this gap by investigating the impact of marketing capabilities on export performance for the low and high involvement exporters.

The results of the study contribute to the understanding of the impact of marketing capabilities on export performance. First, it verifies that marketing capabilities impact export performance leading to export intensity. Second, the effect of the three types of marketing capabilities on export performance is moderated by export involvement. Depending on the level of export involvement, different marketing capbilities are needed to improve export performance. Third, on a theoretical level, the study can explain when and which marketing capabilities contribute to export performance by assessing the differential role of marketing capabilities in export ventures with varying levels of export involvement. As one can argue that marketing capabilities are not the exclusive force that determines export performance, different stages of economic development, product life cycle, and other organizational and environmental factors must also come into play. Fourth, this study reports results obtained from exporting firms in Saudi Arabia in terms of their marketing capabilities and export performance. The findings of this study may be 
transferable to Arab countries and other less developed countries that exhibit similarity in their levels of economic development, industry structure, exporting products, and exporting firms' marketing capabilities.

The results provide significant managerial implications for exporters. Our findings suggest several ways that an exporter can improve export performance. Among the three marketing capabilities, distribution and promotion capabilities show greater significance to export performance for the high involvement exporters. This suggests that the high involvement exporters need to continue upgrading their distribution and promotion capabilities to increase export performance. As shown in the results, both capabilities have high impact on export performance leading to export intensity. The larger impact of distribution and promotion capabilities found in this study may be partially due to the fact that the quality of intermediate (i.e. industrial) goods produced by many Saudi exporters are on par with international standards. Many exporters' product technology and quality have been provided by Western companies in joint venture partnerships. This may be true for exporters in other countries whose primary exporting products are standardized or commoditized. Therefore, marketing aspects such as efficient distribution capability and effective promotion capability take on an added dimension to enhance export performance.

For the low involvement exporters, the distribution and product capabilities have significant impacts on export performance. To convert the low involvement exporters to more active high involvement exporters, government export assistance programs need to provide support and assistance in establishing the distribution channels and cultivating exportable products to global markets (Leonidou, Palihawadana \& Theodosious et al., 2011; Sousa \& Bradley, 2009).

Although this study has made several important contributions to marketing literature, it is important to consider its limitations. Most significantly, this study utilized cross-sectional survey data to test the proposed conceptual model. Survey methodology, measuring a single point in time, may limit the generalizability of the findings to other environmental and country contexts, because this study focused on the manufacturing sector in a country where industrialization is still being formed. Future research should validate the findings of this study using data obtained from other countries. The approach used in this study takes a conventional view of marketing capability. However, a broader conceptualization of marketing capabilities may dictate a broader operational definition of marketing-related capabilities. Future research should test the impact of other non-traditional types of marketing capabilities on export performance. As organization-level marketing capabilities and competitive advantages influence performance, they will continue to be of great interest to managers and researchers. Furthermore, refinement of the scales used to represent export marketing capabilities is an area for further research. Finally, developing marketing capabilities is, by definition, a learning process. Therefore, aspects related to what factors enable development of capabilities and what factors hinder their development is another fruitful area of research.

\section{Acknowledgment}

The authors extend their appreciation to the Deanship of Scientific Research at King Saud University for funding the work through the Research Group Project No. RGP-VPP011.

\section{References}

Al-Aali, A. 1995. 'Obstacles facing Saudi-Arabian food and chemical exporters', International Journal of Commerce and Management, 5(3): 17-31.

Anderson, J.C. 1987. 'An approach to confirmatory measurement and structural equation modeling of organizational properties', Management Science, 33(4): 931 .

Bagozzi, R.P. \& Phillips, L.W. 1982. 'Representing and testing organizational theories: a holistic construal', Administrative Science Quarterly, 16(3): 459-489.

Beamish, P.W. \& Munro, H. 1987. 'Exporting for success as a small Canadian manufacturer', Journal of Small Business and Entrepreneurship, 4(4): 38-43.

Bello, D.C., Chelariu, C. \& Zhang, L. 2003. 'The antecedents and performance consequences of relationalism in export distribution channels', Journal of Business Research, 56(1): 1-16.

Bingham, C.B., Eisenhardt, K.M. \& Furr, N.R. 2007. 'What makes a process a capability? Heuristics, strategy, and effective capture of opportunities', Strategic Entrepreneurship Journal, 1(1-2): 27-47.

Blesa, A. \& Ripolle, M. 2008. 'The influence of marketing capabilities on economic international performance', International Marketing Review, 25(6): 651-673.

Bo, R. 2007. 'International marketing behavior amongst exporting firms', European Journal of Marketing, 41(1): 181-198.

Brouthers, L.E. \& Nakos, G. 2005. 'The role of systematic international market selection on small firms' export performance', Journal of Small Business Management, 43(4): 363-81.

Brouthers, L. E., Nakos, G., Hadjimarcou, J. \& Brouthers, K.D. 2009. 'Key factors for successful export performance for small firms,' Journal of International Marketing, 17(3): $21-38$

Cavusgil S.T., Chan, K. \& Zhang, C. 2003. 'Strategic orientation in export pricing: A clustering approach to create firm taxonomies', Journal of International Marketing, 11(1): 47-72. 
Czinkota, M. R. \& Ronkainin, I. A. 2001. International marketing. USA: The Dryden Press.

Day, G. S. 1994. 'The capabilities of market-driven organizations', Journal of Marketing, 58(4): 37-52.

Diamantopolous, A. \& Inglis, K. 1988. 'Identifying differences between high- and low- involvement exporters', International Marketing Review, 5(2): 52-60.

Diamantopoulos, A. \& Winklhofer, H.M. 2001. 'Index construction with formative indicators,' Journal of Marketing Research, 38(2): 269-277.

Dominguez, L.V. \& Sequira, C.G. 1993. 'Determinants of LDC exporters' performance: A cross-national study', Journal of International Business Studies, 24(1): 19-40.

Eisenhardt, K.M. \& Martin, J.A. 2000. 'Dynamic capabilities: What are they?', Strategic Management Journal, 21(11-12): 1105-1121.

Ethiraj, S.K., Kale, P., Krishnan, M.S. \& Singh, J.V. 2005. 'Where do capabilities come from and how do they matter? A study in the software services industry', Strategic Management Journal, 26(1): 25-45.

Eusebio, R., Andreu, J.L. \& Belbeze, M.P.L. 2007. 'Management perception and marketing strategy in export performance', Journal of Fashion Marketing and Management, 11(1): 24-40.

Fernhaber, S.A. \& McDougall, P. 2005. 'New venture growth in international markets: The role of strategic adaptation and networking'. In Shepherd, D.A. \& Katz, J.A. (Eds.). International entrepreneurship. London: Elsevier, p.p.111-37.

Fornell, C. \& Larcker, D.F. 1981. 'Evaluating structural equation models with unobservable variables and measurement error', Journal of Marketing Research, 18(2): 39-50.

Hooley, G.J., Greenley, G.E., Cadogan, W. \& Fahy, J. 2005. 'The performance impact of marketing resources', Journal of Business Research, 58(1): 18-27.

Hultman, M., Katsikeas, C.S. \& Robson, M.J. 2011. 'Export promotion strategy and performance: The role of international experience', Journal of International Marketing, 19(4): 17-39.

Jaworski, B.J. \& Kohli, A.K. 1993. 'Market orientation: antecedents and consequences', Journal of Marketing, 57(3): 53-70.

Katsikeas, C.S., Leonidou, L.C. \& Morgan, N.A. 2000. 'Firm-level export performance assessment: review, evaluation, and development', Journal of the Academy of Marketing Science, 28(4): 493-511.

Keegan, W.J. 2002. Global marketing management. Upper Saddle River, NJ: Prentice Hall.
Lages, L.F., \& Montgomery, D.B. 2004. 'Export performance as an antecedent of export commitment and marketing strategy adaption: Evidence from small and medium-sized exporters', European Journal of Marketing, 38(9/10): 1186-1214.

Lages, L.F., Silva, G. \& Styles, C. 2009. 'Relationship capabilities, quality, and innovation as determinants of export performance,' Journal of International Marketing, 17(4): 47-70.

Lages, L.F., Jap, S.D. \& Griffith, D.A. 2008. 'The role of past performance in export ventures: A short-term reactive approach,' Journal of International Business Studies, 39(2): 304-325.

Lee, C. \& Griffith, D.A. 2004. 'The marketing strategyperformance relationship in an export-driven developing economy', Journal of International Marketing Review, 21(3): 321-334.

Leonidou, L.C. 2004. 'An analysis of the barriers hindering small business export development', Journal of Small Business Management, 42(3): 279-302.

Leonidou, L.C. 2011. 'Factors stimulating export business: An empirical investigation,' Journal of Applied Business Research, 142(23): 43-68.

Leonidou, L.C. \& Katsikeas, C. 1996. 'The export development process: an integrative review of empirical models', Journal of International Business Studies, 27(3): 517-51.

Leonidou, L.C., Katsikeas, C. S. \& Samiee, S. 2002. 'Marketing strategy determinants of export performance: A meta-analysis,' Journal of Business Research, 55(1): 51-67.

Leonidou, L.C., Palihawadana, D. \& Theodosiou, M. 2011. 'National export-promotion programs as drivers of organizational resources and capabilities: Effects on strategy, competitive advantage, and performance,' Journal of International Marketing, 19(2): pp. 1-29.

Li, T. \& Calantone, R. 1998. 'The impact of market knowledge competence on new product advantage: Conceptualization and empirical examination', Journal of Marketing, 62(4): 13-29.

Lim, J.S., Sharkey, T. \& Kim, K. 1993. 'Determinants of international marketing strategy', Management International Review, 33(2): 103-120.

Lim, J.S., Sharkey, T. \& Kim, K. 1996. 'Competitive environmental scanning and export involvement: an initial inquiry', International Marketing Review, 13(1): 65-80.

Lim, J.S., Sharkey, T. \& Heinrichs, J. 2006. 'Strategic impact of new product development on export involvement,' European Journal of Marketing, 40(1/2): 44-60.

Ling-yee, L. 2004. 'An examination of the foreign market knowledge of exporting firms based in the People's 
Republic of China: Its determinants and effect on export intensity', Industrial Marketing Management, 33(7): 56172.

Louter, P.J., Ouwerkerk, C. \& Bakker, B.A. 1991. 'An inquiry into successful exporting', European Journal of Marketing, 25(6) 7-23.

Lu, J.W. \& Beamish, P.W. 2001. 'The internationalization and performance of SMEs,' Strategic Management Journal, 22(6/7): 565-86.

Makadok, R. 2001. 'Toward a synthesis of the resourcebased and dynamic-capabilities views of rent creation', Strategic Management Journal, 22(5): 387-401.

Ministry of Commerce and Industry. 2009. 'List of certificates of origin issued'. Riyadh, Saudi Arabia.

Moorman, C. \& Slotegraaf, R.J. 1999. 'The contingency value of complementary capabilities in product development,' Journal of Marketing Research, 36(2): 239257.

Morgan, N.A., Vorhies, D.W. \& Mason, C.H. 2009. 'Research notes and commentaries market orientation, marketing capabilities, and firm performance', Strategic Management Journal, 30(8): 909-920.

Murray, J.Y., Gao, G.Y. \& Kotabe, M. 2011. 'Market orientation and performance of export ventures: The process through marketing capabilities and competitive advantages', Journal of the Academy of Marketing Science, 39(2): 252269.

Narver, J.C. \& Slater, S.F. 1990. 'The effect of a market orientation on business profitability', Journal of Marketing, 54(4): 20-35.

Nath, P., Nachiappan, S. \& Ramanathan, R. 2010. 'The impact of marketing capability, operations capability and diversification strategy on performance: A resource-based view', Industrial Marketing Management, 39(2): 317-329.

Newbert, S. L. 2007. 'Empirical research on the resourcebased view of the firm: An assessment and suggestions for future research', Strategic Management Journal, 28(2): 121146

Osman, M., Ramayah, T. \& Ng, K.S. 2009. 'Exporting to China and ASEAN countries: Perceived advancement in marketing competencies and export performance', Journal of US-China Public Administration, 6(1): 15-22.

Özsomer, Ay.egül \& Gençtürk, E. 2003. 'A resource-based model of market learning in the subsidiary: The capabilities of exploration and exploitation,' Journal of International Marketing, 11(3): 1-29.

Slater, S. F. \& Narver, J. C. 1995. 'Market orientation and the learning organization', Journal of Marketing, 59(3): 6374.
Song, M., Benedetto, A. D. \& Nason, R.W. 2007. 'Capabilities and financial performance: The moderating effect of strategic type', Journal of the Academy of Marketing Science, 35(1): 18-34.

Sousa, C.M. \& Alserhan, B.A. 2002. 'An investigation into the antecedents of the export performance literature'. Paper presented at the $28^{\text {th }}$ EIBA Conference, Athens University of Economics and Business, Athens, 8-10 December.

Sousa, C.M. \& Bradley, F. 2009. 'Effects of export assistance and distributor support on the performance of SMEs', International Small Business Journal, 27(6): 681701.

Style, C. \& Ambler, T. 2000. 'The impact of relational variable on export performance: An empirical investigation in Australia and the UK', Australian Journal of Management, 25(2): 261-281.

Teece, D.J. \& Al-Aali, A. 2011. 'Knowledge assets, capabilities and the theory of the firm'. In Easterby-Smith, M. \& Lyles, M.A (Eds.).Handbook of organizational learning and knowledge management. $2^{\text {nd }}$ Edition. Wiley Publishing, pp. 505-534.

Teece, D.J., Pisano, G. \& Shuen, A. 1997. 'Dynamic capabilities and strategic marketing', Strategic Management Journal, 18(7): 509-535.

Terpstra, V. \& Sarathy, R. 2000. International marketing. Oak Brook, IL: The Dryden Press.

Tooksoon, P. \& Mohamad, O. 2010. 'Marketing capability and export performance: The moderating effect of export dependence', The South East Asian Journal of Management, 4(1): 39-52.

Tsai, M. \& Shih, C. 2004. 'The impact of marketing knowledge among managers on marketing capabilities and business performance', International Journal of Management, 21(4): 524-30.

Vorhies, D.W. \& Morgan, N.A. 2003. 'A configuration theory assessment of marketing organization fit with business strategy and its relationship with marketing performance', Journal of Marketing, 67(1): 100-115.

Vorhies, D.W. \& Morgan, N.A. 2005. 'Benchmarking marketing capabilities for sustainable competitive advantage', Journal of Marketing, 69(1): 80-94.

Weerawardena, J. 2003a. 'The role of marketing capability in innovation-based competitive strategy', Journal of Strategic Marketing, 11(1): 15-35.

Weerawardena, J. 2003b. 'Exploring the role of market learning capability in competitive strategy', European Journal of Marketing, 37(3/4): 407-429.

Wilkinson, T. \& Brouthers, L.E. 2006. 'Trade promotion and SME export performance', International Business Review, 15(3): 233-52. 
Yeniyurt, S., Cavusgil, S.T. \& Hult, G.T.M. 2005. 'A global market advantage framework: The role of global market knowledge competencies', International Business Review, 14(1): 1-19.

Zahara, S., Ireland, R.D. \& Hitt, M. 2000. 'International expansion by new venture firms: International diversity, mode of entry, technological learning and performance', Academy of Management Journal, 4(5): 925-50.

Zhang, C., Cavusgil, S.T. \& Roath, A.S. 2003. 'Manufacturer governance of foreign distributor relationships: Do relational norms enhance competitiveness in the export market?' Journal of International Business Studies, 34(6): 550-566.

Zott, C. 2003. 'Dynamic capabilities and the emergence of intra industry differential performance: Insights from a simulation study,' Strategic Management Journal, 24(2): 97-125.

Zou, S., Fang, E. \& Zhao, S. 2003. 'The effect of export marketing capabilities on export performance: An investigation of Chinese exporters', Journal of International Marketing, 11(4): 32-55. 


\section{Appendix}

Measures

1. Product Capability (overall evaluation of your company's situation comparing to its competitors in the overseas markets, 1 $=$ Much lower; 5 = Much higher)

- The quality of exported products compared to that of competitors in the overseas market.

- The differentiation of exported products compared to that of competitors in the overseas market.

2. Promotion Capability (overall evaluation of your company's situation comparing to its competitors in the overseas markets, 1 = Much lower; 5 = Much higher)

- The promotion budget compared to that of competitors in the overseas market.

- The effectiveness of the promotion activities compared to that of competitors in the overseas market.

3. Distribution Capability (overall evaluation of your company's situation comparing to its competitors in the overseas markets, 1 = Much lower; 5 = Much higher)

- The distribution budget compared to that of competitors in the overseas market.

- The effectiveness of the distribution activities compared to that of competitors in the overseas market.

4. Export Performance $(1=$ Strongly disagree; $5=$ Strongly agree $)$

- $\quad$ Exporting has contributed noticeably to my company's sales growth.

- Exporting has contributed noticeably to my company's market share growth.

- Exporting has contributed to increased competitiveness of my company.

- The overall company export performance compared to that of competitors in the overseas market is much higher.

5. Export Intensity

- The percentages of exporting sales out of my company's total sales last two years were: $\%$ $\%$

6. Export Involvement

- $\quad$ Please answer this question related to the Export Department, and choose only one answer. _Yes, there is a department dedicated to exporting or overseas sales.

- The exporting department is established years ago.

- The number of full-time export department employees are employees.

_ No, there is no department dedicated to exporting or overseas sales. 